\title{
Company Responses to Human Rights Reports: An Empirical Analysis
}

\author{
Menno T. KAMMINGA*
}

\begin{abstract}
How do companies respond to their critics? Are there significant differences in responsiveness between industrial sectors, between the countries in which companies are based, and between the companies themselves? Do responses reflect the belief that companies have a responsibility to respect human rights? Do companies that participate in the UN Global Compact react more responsibly than those that do not? This article attempts to answer these questions by examining company responses to civil society reports contained in the company response database of the Business \& Human Rights Resource Centre. The analysis covers responses to 1877 requests made by the Resource Centre from 2005-2014.
\end{abstract}

Keywords: civil society, company response rate, corporate due diligence

\section{INTRODUCTION}

Although much has been written on business and human rights little is known about how companies actually react to allegations of human rights abuse. Are companies inclined to respond to their critics? Are there significant differences in responsiveness between industrial sectors, between the countries in which companies are based, and between the companies themselves? What is the nature of company responses to critical reports from civil society? Do these responses reflect the belief that companies have a responsibility to respect human rights? Are companies that have committed themselves to international standards and initiatives such as the UN Global Compact more inclined to respond than those that have not committed themselves in this way?

There are plenty of empirical studies analysing and comparing corporate policy statements and codes of conduct adopted by companies. ${ }^{1}$ There also is no lack of empirical research into human rights abuses by companies. Investigative journalists and

\footnotetext{
* Emeritus Professor of International Law at Maastricht University and former member of the Board of Trustees, Business \& Human Rights Resource Centre. Comments by Christopher Avery and Mauricio Lazala and research assistance by Catalina Aristizabal, Zoja Bajzelj, Stephanie Goudriaan, and Wanghaomeng Wang are all gratefully acknowledged. I am also grateful to the anonymous reviewers and the editors-in-chief of this journal for their detailed comments and suggestions. Initial research for this project was conducted by Lynn Schweisfurth in her thesis 'The Corporate Response to Allegations of Human Rights Abuse: An Analysis of Responses Published by the Business \& Human Rights Resource Centre' (awarded under the European Master's Degree Program in Human Rights and Democratization).

1 See, e.g., Rhys Jenkins, ‘Corporate Codes of Conduct. Self-Regulation in a Global Economy' United Nations Research Institute for Social Development, Technology, Business and Society Programme Paper, 2001; Ans Kolk and 
NGOs such as Amnesty International, Global Witness, Human Rights Watch, SOMO, and numerous smaller local NGOs have conducted research both on abuses by individual companies and on abuses in particular industrial sectors. But there is no such thing as an annual report on corporate human rights abuses worldwide. It is therefore difficult to obtain a comprehensive overview of global patterns and trends of corporate abuse. A 2008 study conducted by the former UN Special Representative on Business and Human Rights (SRSG), John Ruggie, that compares corporate human rights violations, among other things, by their nature (direct and indirect), by region, and by industrial sector may be the only empirical survey providing some insight into these questions. ${ }^{2}$

In a similar vein, although critical reports by civil society organizations abound, what is lacking is empirical research into how companies respond to the allegations raised in them. Former SRSG John Ruggie has propagated a 'knowing and showing' approach, based on the idea that companies should continuously identify, assess, and address their human rights impact by conducting a due diligence process. ${ }^{3}$ However, until all companies are doing so effectively, 'naming and shaming' continues to be the principal method by which companies are held accountable for human rights abuses. This occurs primarily through NGO reports and investigative journalism. How companies respond (or do not respond) to such reports is therefore of great interest. The responses substantially contribute to the body of knowledge on corporate attitudes towards human rights and thereby provide clues for campaigners and regulators. They also add a reality check to debates dominated by standard-setting and national action plans.

One reason for the scarcity of empirical research into responses to human rights reports is the lack of reliable data. It would be very difficult to approach all authors of human rights reports and ask them to provide copies of the responses they received. Due to lack of time, few NGOs and journalists would be willing to co-operate with such an exercise. In 1996, an article by Stanley Cohen was published on governmental responses to human rights reports. Cohen distinguished three types of governmental reactions: official denial, attack on the critic, and (partial) acknowledgment of the criticism. ${ }^{4}$ In addition, there were of course governments that did not react at all. But he provided no figures, apparently because they were not available. ${ }^{5}$

Fortunately, research into company responses to human rights criticism does not face the difficulty of a lack of data. Since 2005, the Business \& Human Rights Resource Centre (hereinafter the Resource Centre) has invited companies to respond to allegations of corporate misconduct raised by civil society. The Resource Centre is an independent non-profit organization that tracks the human rights performance (both positive and

(F'note continued)

Rob van Tulder, 'Setting New Global Rules? TNCs and Codes of Conduct' (2005) 14 Transnational Corporations No. $3,1$.

2 UN Human Rights Council, 'Corporations and Human Rights: A Survey of the Scope and Patterns of Alleged Corporate-Related Human Rights Abuse', A/HRC/8/5/Add.2 (23 May 2008); see also John G Ruggie, Just Business: Multinational Corporations and Human Rights (New York; London: W W Norton \& Company, 2013).

3 UN Human Rights Council, 'Business and Human Rights: Further Steps toward the Operationalization of the "Protect, Respect and Remedy" Framework', A/HRC/14/27 (9 April 2010) para. 80.

4 A possible typology for categorizing company responses is discussed at the end of this paper.

5 Stanley Cohen, 'Government Response to Human Rights Reports: Claims, Denials and Counterclaims' (1996) 18 Human Rights Quarterly 517, 521. 
negative) of companies around the world. Its website currently contains information on over 5,600 companies in more than 180 countries. ${ }^{6}$ Before posting a critical report on its website the Resource Centre invites companies to respond to specific allegations made against them. ${ }^{7}$ Any company responses are then posted together with the report. The Resource Centre formulates the purpose of its company response mechanism as follows:

This process encourages companies to publicly address human rights concerns, and provides the public with both the allegations and the company's comments in full. In some cases this process helps to bring about resolution of the issues. In other cases it has led to dialogue between the company and those raising the concerns. In all cases it has increased transparency. ${ }^{8}$

In 2012, for example, the Resource Centre sought responses to a report by Global Witness on lobbying activities by the United States Chamber of Commerce against implementation of a Dodd-Frank Act provision that would require companies registered with the United States Securities and Exchange Commission (SEC) to carry out supply chain due diligence on 'conflict minerals' from the Democratic Republic of Congo. ${ }^{9}$ The report focused on the ties of 11 electronics and automotive companies that use these minerals with the Chamber of Commerce. The Resource Centre received responses from seven of these companies, posted these on its website, and drew attention to the four companies that had failed to respond. Microsoft, General Electric, and Motorola Solutions disassociated themselves from the Chamber's position and the SEC soon afterwards adopted the conflict minerals provisions the Chamber had objected to. Thus, by shaming companies into taking a position the Resource Centre was able to make clear that the Chamber's position was not unanimously supported by its members. This enabled the SEC to adopt the legislative measures desired by human rights groups.

\section{Methodology}

\section{A. Source of Information and Focus of Analysis}

The Resource Centre's online database containing the full text of both civil society reports transmitted and company responses to these reports is a treasure trove of information. In 2008, the SRSG observed in one of his first reports to the UN Human Rights Council: 'In the absence of a universal database that stores allegations of abuse, the Resource Centre's online library is the most comprehensive, objective source available'. ${ }^{10} \mathrm{He}$ therefore used the entries in the Resource Centre's corporate

\footnotetext{
6 Business \& Human Rights Resource Centre, 'Introduction' http://business-humanrights.org/pt/node/100990 (accessed 24 July 2015).

7 In some cases responses are not requested by the Resource Centre, e.g. when a report does not make serious allegations against specific companies or when responses are already in the public domain. It should also be noted that some human rights reports cover alleged abuses by more than one company. In such cases individual companies may feel under less pressure to respond.

8 Business \& Human Rights Resource Centre, 'Company Response Rates', http://business-humanrights.org/en/ company-response-rates (accessed 24 July 2015).

9 Business \& Human Rights Resource Centre, 'Lobbying "seeking to undermine” Dodd-Frank conflict minerals legislation' http://business-humanrights.org/en/lobbying-seeking-to-undermine-dodd-frank-conflict-minerals-legislation (accessed 24 July 2015).

10 'Survey of Corporate-Related Human Rights Abuse', note 2, 8.
} 
response database (approximately 320 at that time) to obtain an overview of patterns of corporate impact on human rights.

Professor Ruggie's qualification of the importance of the database as a comprehensive, objective source of information about corporate abuse applies even more strongly today, because the Resource Centre has significantly expanded its activities since 2008. The Resource Centre's website is now in seven languages: English, Arabic, Chinese, French, Portuguese, Russian, and Spanish. The Research Centre employs regional researchers based in Brazil, Colombia, Hong Kong, India, Kenya, Japan, Lebanon, Myanmar, Mexico, Senegal, South Africa, United Kingdom, Ukraine, and the United States. Among their tasks is the collection of civil society reports that are suitable for posting on the Resource Centre's website and to try and elicit responses to these reports if companies have not yet responded.

What follows below is a quantitative analysis of the information contained in the publicly accessible company response database of the Resource Centre, covering all responses requested by the Resource Centre from the establishment of the mechanism in 2005 until January 2014. ${ }^{11}$ The data will be analysed in terms of industrial sectors (which sectors are least responsive?), origin or home base of the company (in which countries are companies least responsive?), individual companies (which companies are least responsive?), and international instruments (do previous commitments influence the response rate of companies?).

The online database consists of a lengthy Excel spreadsheet with columns listing the company name, industrial sector, country of company headquarters, country of alleged abuse, date, issue, whether the company responded, link to the company response, and link to the company webpage. The information is listed alphabetically by company name. Calculations on the data in this spreadsheet were carried out with the help of a team of four graduate students. Because of the high degree of professionalism and long experience of the Resource Centre no attempt was made to second-guess the information in the database. Data such as company names and the countries where companies are headquartered were simply copy-pasted from the database. Only with respect to the classification of industrial sectors, a differing system was adopted for reasons that are explained below.

The analysis is subject to some important caveats. Although the Resource Centre continues to increase its worldwide coverage, its response mechanism does not cover all civil society reports on corporate abuses that have been made public. More fundamentally, this article offers an analysis of company responses and non-responses to civil society reports. It is not an examination of the extent to which companies actually respect human rights. Even less is it an attempt to examine the effectiveness of the Resource Centre's company response mechanism. That would require an entirely different methodology.

\section{B. Response Rate}

The UN Guiding Principles on Business and Human Rights (Guiding Principles) endorsed by the UN Human Rights Council in 2011 set out a 'global standard of

11 Business \& Human Rights Resource Centre, 'Company Response Rates', http://business-humanrights.org/en/ company-response-rates (accessed 24 July 2015). 
expected conduct for all business enterprises wherever they operate'. ${ }^{12}$ Although the Guiding Principles are not by themselves legally binding they represent at a minimum ethical standards with a wide backing. ${ }^{13}$ The Guiding Principles provide that companies have a responsibility to respect human rights. In order to prevent human rights abuses, they should carry out 'human rights due diligence'. One crucial component of the due diligence process is 'meaningful consultation with potentially affected groups and other relevant stakeholders'. ${ }^{14}$ Clearly, failure even to respond to civil society reports transmitted by the Resource Centre is incompatible with this obligation to consult. The Resource Centre's staff tenaciously pursues responses by follow-up messages and phone calls to officials at different levels of the company. A non-response must therefore be regarded as a deliberate decision on the part of a company, and not as a mere oversight.

In the period covered by the survey, the Resource Centre requested companies to respond to human rights reports on 1,877 occasions. Companies sent 1,317 responses to these requests, which represents an overall average response rate of 70 per cent. This average response rate remained remarkably stable throughout the period. It was not noticeably influenced by external events such as the BP oil spill in the Mexican Gulf or the Rana Plaza collapse. Thus, 30 per cent of companies essentially failed to meet perhaps the most basic part of their due diligence responsibility by not reacting to the Resource Centre's invitation to respond.

The response rate reflects the percentage of reports to which a company has responded to the Resource Centre. The response rate may be calculated by industrial sector, by home country, and by company. That classification constitutes the basic structure of the present article. As will be seen below, the response rate may differ significantly between companies. It should be acknowledged from the outset, however, that a company response to a critical civil society report is not necessarily a positive sign. The Resource Centre has recently started posting the response rate of each company on its website. The resulting higher visibility of a company's response rate may well increase the pressure on companies to respond. But if this merely results in more pro forma responses from corporate public relations departments, no progress in respect for human rights will be made. Nevertheless, the absence of any reaction at all is always a negative sign. It indicates unwillingness to engage with civil society on important issues relating to the company's conduct and implies a breach of the due diligence requirement contained in a company's responsibility to respect human rights.

\section{RESULTS}

\section{A. Industrial Sectors}

Industrial activities may of course be classified in many different ways. Stock indexes such as Down Jones and Standard \& Poor's have developed their own classification schemes.

\footnotetext{
12 UN Human Rights Council, 'Guiding Principles on Business and Human Rights: Implementing the United Nations "Protect, Respect and Remedy" Framework', A/HRC/17/31 (21 March 2011), Commentary to Principle 11.

13 See John H Knox, 'The Ruggie Rules: Applying Human Rights Law to Corporations' in Radu Mares (ed.), The UN Guiding Principles on Business and Human Rights (Leiden: Brill/Nijhoff Publishers, 2011) 51-84, Ch. 2.

14 'Guiding Principles on Business and Human Rights', note 12, Principle 18.
} 
The Resource Centre has adopted yet another classification scheme for its company responses database. The present article follows the classification of industrial sectors adopted in the aforementioned study carried out in 2008 by SRSG John Ruggie. ${ }^{15}$ Professor Ruggie's survey of corporate-related human rights abuse was conducted on the basis of information contained in the Resource Centre's company response database as well. By following Ruggie's classification scheme, we are therefore able to compare his findings with our own and to establish whether any significant changes have occurred since 2008. The figures in the second column of Table 1 are taken from the SRSG's study. The figures in the third and fourth columns are cumulative since the start of the company response mechanism in 2005.

Table 1: Reports transmitted and response rate per industrial sector

\begin{tabular}{lccc}
\hline Industrial sector & $\begin{array}{c}\text { Reports transmitted } \\
\text { until 2008 }\end{array}$ & $\begin{array}{c}\text { Reports transmitted } \\
\text { until 2014 }\end{array}$ & $\begin{array}{c}\text { Response } \\
\text { rate }\end{array}$ \\
\hline Extractive & $28 \%$ & $29 \%$ & $72 \%$ \\
Financial services & $8 \%$ & $10 \%$ & $67 \%$ \\
Food and beverage & $7 \%$ & $8 \%$ & $86 \%$ \\
Heavy manufacturing & $4 \%$ & $6 \%$ & $67 \%$ \\
Infrastructure and utilities & $9 \%$ & $8 \%$ & $63 \%$ \\
Information technology & $5 \%$ & $16 \%$ & $68 \%$ \\
Pharmaceutical and chemical & $12 \%$ & $5 \%$ & $63 \%$ \\
Retail and consumer products & $21 \%$ & $15 \%$ & $71 \%$ \\
Other & $6 \%$ & $3 \%$ & $50 \%$ \\
Total & $100 \%$ & $100 \%$ & \\
\hline
\end{tabular}

The table shows that, generally speaking, the comparative number of reports per industrial sector has remained remarkably stable since 2008. By far the largest number of reports continues to relate to the extractive sector (extraction of oil, gas, minerals, and metals). This has long been a familiar pattern. Some of the worst abuses tend to occur in connection with extractive activities in conflict zones. ${ }^{16}$ The largest relative increase during the past nine years has occurred in the number of reports on abuses in the information technology sector, where the percentage of allegations has tripled. Such reports tend to criticize working conditions in companies supplying components for the electronics industry and corporate assistance to governments to help them restrict internet access.

While, as we have seen in the methodology section, the average response rate is 70 per cent, there are significant differences in responsiveness between industrial sectors. By far the most responsive are companies in the food and beverage sector. Companies in the category 'Other' (primarily conglomerates covering different industrial sectors) are least responsive. Companies in consumer-orientated sectors are more inclined to respond

\footnotetext{
15 'Survey of Corporate-Related Human Rights Abuse', note 2, 9. Ruggie did not gather data on other aspects covered by the present paper (home states, companies, and international instruments).

16 OECD, 'Multinational Enterprises in Situations of Violent Conflict and Widespread Human Rights Abuses', OECD Working Papers on International Investment, No. 2002/1, http://www.oecd.org/countries/myanmar/WP-2002_1.pdf (accessed 24 July 2015).
} 
to critical reports from civil society than are faceless conglomerates. This is probably because consumer brands are more susceptible to reputation damage. ${ }^{17}$

Nike and Shell are classic examples of consumer brands that suffered considerable reputation damage, dropping sales, and diminished share value following the publication of critical human rights reports. Throughout the 1990s, reports were published that Nike shoes were manufactured under sweatshop conditions in Asia. By 1998, its CEO admitted 'The Nike product has become synonymous with slave wages, forced overtime, and arbitrary abuse' and accepted that American consumers did not want to buy products made in abusive conditions. ${ }^{18}$ In 1995, Greenpeace called for a consumer boycott to put pressure on Shell not to sink the disused Brent Spar oil storage buoy in the Atlantic. When Shell refused to comply initially, the company suffered a 20 per cent reduction in petrol sales in Germany. Ironically, Greenpeace's campaign later turned out to be based on erroneous figures. ${ }^{19}$ Both Nike and Shell took extensive measures and changed their policies to prevent the recurrence of reputation damage. ${ }^{20}$

\section{B. Company Home States}

The SRSG's 2008 study showed in which regions of the world corporate human rights violations were most prone to occur. ${ }^{21}$ However, it did not try to extract country-specific information from the Resource Centre's company responses database, probably because this might have risked offending certain UN member states. Such country-specific information is, however, accessible in the database. This makes it possible to find out in which countries companies are most often accused of having committed abuses (either in their own countries or abroad). Furthermore, it can be established whether or not there is a difference in response rate between companies depending on the country in which they are based. The table below indicates in which countries companies received 15 or more invitations to respond to civil society reports and the response rate per corporate home state.

Table 2: Reports transmitted and response rate per home state

\begin{tabular}{lcc}
\hline Home state & Reports transmitted & Response rate \\
\hline Australia & 43 & $77 \%$ \\
Brazil & 22 & $86 \%$ \\
Canada & 110 & $74 \%$ \\
China & 94 & $40 \%$ \\
\hline
\end{tabular}

\footnotetext{
17 Doreen McBarnet, 'Corporate Social Responsibility beyond Law, through Law, for Law: The New Corporate Accountability', in Doreen McBarnett, Aurora Voiculescu, and Tom Cambell (eds.), The New Corporate Accountability (Cambridge: Cambridge University Press, 2009) 16.

18 John H Cushman, 'Nike Pledges to End Child Labor and Apply US Rules Abroad', New York Times (13 May 1998).

19 Judy Kuszewski and Yasmin Crowther, 'Brent Spar: Battle that Launched Modern Activism', Ethical Corporation (2 May 2010), http://www.ethicalcorp.com/communications-reporting/brent-spar-battle-launched-modern-activism (accessed 24 July 2015).

20 On Nike's 'path to corporate responsibility', which leads from outright denial of allegations to gradually acknowledging them and integrating response mechanisms into its core business operations, see Simon Zadek, 'The Path to Corporate Responsibility' (2004) 82 Harvard Business Review 125.

21 'Survey of Corporate-Related Human Rights Abuse', note 2, 10.
} 
Table 2: (Continued)

\begin{tabular}{lcc}
\hline Home state & Reports transmitted & Response rate \\
\hline Colombia & 20 & $80 \%$ \\
France & 79 & $80 \%$ \\
Germany & 87 & $86 \%$ \\
India & 56 & $41 \%$ \\
Israel & 20 & $45 \%$ \\
Italy & 29 & $62 \%$ \\
Japan & 29 & $66 \%$ \\
Malaysia & 15 & $80 \%$ \\
Mexico & 23 & $65 \%$ \\
Netherlands & 69 & $90 \%$ \\
Republic of Korea & 32 & $75 \%$ \\
Russia & 18 & $39 \%$ \\
South Africa & 40 & $93 \%$ \\
Spain & 25 & $60 \%$ \\
Sweden & 29 & $93 \%$ \\
Switzerland & 46 & $78 \%$ \\
Taiwan & 29 & $66 \%$ \\
United Kingdom & 198 & $71 \%$ \\
United States & 511 & $72 \%$ \\
\hline
\end{tabular}

The figures show that there are important differences in the number of reports transmitted per corporate home state. By far the largest number of reports was transmitted to companies based in the United States, followed by the United Kingdom, Canada, and other major Western states. These reports generally related to conduct by multinational corporations outside their home states.

There also are important differences in response rates. Companies in four countries have an average response rate that is significantly below par: China, India, Israel, and Russia. Reports about abuses by China-based companies mostly concern working conditions, environmental and health concerns, and forced relocation. Reports about Indian companies are mostly concerned with child labour, environmental and health issues, workers' rights, and forced resettlement. Reports about Israeli companies are mostly about companies' support for illegal settlements. Report about Russian companies mostly concern environmental and health issues, and workers' rights.

More than half of the reports about China-based companies relate to alleged abuses outside China. Reports about companies based in India, Israel and Russia, on the other hand, mainly refer to abuses within the home state. The response rate in these four countries is higher with regard to reported abuses in the corporations' home states, apparently reflecting an assumption that causing extraterritorial harm is less problematic and requires less justification than harming one's own country's citizens. ${ }^{22}$ India and

\footnotetext{
22 This attitude by companies is reminiscent of the position taken by some states-notably the United States and Israel - that the human rights treaties to which they are parties are not applicable to their extraterritorial conduct. Fourth Periodic Report of the United States of America, ICCPR, 20 May 2012, CCPR/C/USA/4 para. 505; Fourth Periodic Report of Israel, ICCPR, 12 December 2013, CCPR/C/ISR/4 para. 48.
} 
Israel have vibrant civil societies, so unfamiliarity with civil society is not in itself an explanation for the unresponsiveness of Indian and Israeli companies. Interestingly, India and Russia were among the five core sponsors of the resolution by which the UN Human Rights Council adopted the Guiding Principles (the other core sponsors were Argentina, Nigeria, and Norway). ${ }^{23}$ To cynics this may demonstrate that India and Russia did not perceive the Guiding Principles as a major threat to the companies based in their territories.

Multinational corporations are increasingly headquartered in the so-called BRICS (Brazil, Russia, India, China, and South Africa), in particular in China. ${ }^{24}$ This means that civil society reports are increasingly addressing alleged misconduct by companies based in these states. There is no similarity in response rate between the BRICS, however. Companies based in Brazil and South Africa have a response rate that is twice as high as those in China, India, and Russia. The response rates from Brazilian and South African companies even compare favourably with the response rates of companies based in many Western states. It follows that it is too simplistic to assume that companies based in the BRICS are unresponsive merely because they are upstarts not yet experienced at managing their public relations.

\section{Companies}

Which are the world's worst companies in terms of human rights performance? The answer to this question obviously depends on the criteria used. Gross abuses? Violations of the right to life? During the past 10 years, the Berne Declaration (a Swiss NGO) and Greenpeace Switzerland each year presented their Public Eye Awards. In 2015, the awards were presented for the last time. The Lifetime Award for being the most irresponsible company during the 10 year period was bestowed on Chevron, followed by Glencore, and Walmart. ${ }^{25}$ But the criteria used for selecting the recipients of these awards ('irresponsible business practices') are less than straightforward. ${ }^{26}$

If the number of critical reports transmitted by the Resource Centre is used as a yardstick, the results are more equivocal: Shell and Chevron come out on top. But of course this merely indicates in how many instances NGOs and the media produced reports alleging abuses committed by a particular company. The number of reports is not in itself a reliable indicator of abusive corporate conduct. There may be all kinds of extraneous reasons unrelated to the severity of the alleged abuses why a report is or is not produced on a particular company. For example, research on certain companies or companies in certain countries may be easier because the necessary information is more accessible. Also, larger companies may be more likely targets for criticism than smaller ones because of their higher visibility.

23 UN Human Rights Council, Draft Resolution on 'Human Rights and Transnational Corporations and other Business Enterprises', A/HRC/17/L.17/Rev.1 (15 June 2011).

24 UNCTAD, World Investment Report 2015 - Reforming International Investment Governance (2015), http://unctad. org/en/PublicationsLibrary/wir2015_en.pdf (accessed 24 July 2015), 6-8.

25 Berne Declaration, "Chevron wins the Public Eye Lifetime Award, and The Yes Men bury the "Demon of Davos"' (23 January 2015), https://www.bernedeclaration.ch/media/press-release/chevron_wins_the_public_eye_ lifetime_award_and_the_yes_men_bury_the_demon_of_davos/ (accessed 24 July 2015).

26 Berne Declaration, 'Public Eye Awards', https://www.bernedeclaration.ch/tagged/public_eye_awards-1// (accessed 24 July 2015). 
Table 3: Companies to which the largest number of reports were transmitted

\begin{tabular}{|c|c|c|c|}
\hline Company & Sector & Reports transmitted & Response rate \\
\hline Shell (Netherlands/United Kingdom) & Extractive & 34 & $91 \%$ \\
\hline Chevron (United States) & Extractive & 21 & $71 \%$ \\
\hline Anglo Gold Ashanti (South Africa) & Extractive & 16 & $100 \%$ \\
\hline Barrick Gold (Canada) & Extractive & 15 & $100 \%$ \\
\hline Wal-Mart (United States) & Retail & 15 & $80 \%$ \\
\hline Goldcorp (Canada) & Extractive & 13 & $77 \%$ \\
\hline Foxconn (Taiwan) & Information technology & 13 & $77 \%$ \\
\hline BHP Billiton (Australia) & Extractive & 12 & $83 \%$ \\
\hline Microsoft (United States) & Information technology & 12 & $75 \%$ \\
\hline Newmont (United States) & Extractive & 12 & $100 \%$ \\
\hline Total (France) & Extractive & 12 & $83 \%$ \\
\hline
\end{tabular}

As Table 3 shows, companies with the largest number of reports also have an above average response rate, some even 100 per cent. Apparently, being on the receiving end of numerous civil society reports does not cause 'response fatigue'. At the lower end of the scale, the companies listed below scored particularly badly. They each received three or more reports and they responded to a third or fewer of those reports:

Table 4: Companies with the lowest response rate

\begin{tabular}{lccc}
\hline Company & Sector & $\begin{array}{c}\text { Reports } \\
\text { transmitted }\end{array}$ & $\begin{array}{c}\text { Response } \\
\text { rate }\end{array}$ \\
\hline Apple (United States) & $\begin{array}{l}\text { Information technology } \\
\text { Banco Espirito Santo }\end{array}$ & 12 & $33 \%$ \\
China Power Investment Corporation (China) & Financial services & 3 & $33 \%$ \\
& $\begin{array}{c}\text { Infrastructure and } \\
\text { utilities }\end{array}$ & 4 & $0 \%$ \\
China National Petroleum Company (China) & Extractive & 7 & $14 \%$ \\
Endiama (Angola) & Extractive & 3 & $33 \%$ \\
Gilead Sciences (United States) & Pharmaceutical & 3 & $0 \%$ \\
Golden Star Resources (Canada) & Extractive & 4 & $0 \%$ \\
Hindalco (India) & Extractive & 3 & $0 \%$ \\
Huawei Technologies (China) & Information technology & 3 & $33 \%$ \\
Myanmar Oil \& Gas Enterprise (Myanmar) & Extractive & 4 & $25 \%$ \\
Oil \& Natural Gas Corporation (India) & Extractive & 3 & $0 \%$ \\
Zimbabwe Mining Development Corporation & Extractive & 3 & $0 \%$ \\
(Zimbabwe) & & & \\
\hline
\end{tabular}

What is striking about this list_-apart from the fact that most companies conduct their activities in the extractive sector-is that seven of the 12 companies (China Power Investment, China National Petroleum Company, Endiama, Hindalco, Myanmar Oil \& Gas Enterprise, Oil \& Natural Gas Corporation, and Zimbabwe Mining Development Corporation) are state-owned. Apparently, state-owned companies have a tendency to

27 In 2014, Banco Espirito Santo was salvaged from bankruptcy by Portugal's national bank and split in two separate banks. Miles Johnson and Peter Wise, 'Banco Espírito Santo: Family Fortunes', Financial Times (11 September 2014). 
assume that they are immune from criticism and therefore do not need to bother with community relations.

Typical among this group of companies is China National Petroleum Company (CNPC), China's largest oil and gas producer. CNPC is a state-owned conglomerate to which the Resource Centre transmitted seven critical reports, all relating to the human rights impact of the Shwe gas project in Myanmar and the Myanmar-China oil and gas pipeline project. The reports alleged that CNPC was complicit in abuses such as forced labour, killings, and land seizure. After ignoring the first six reports, CNPC sent a detailed response to the seventh report, possibly indicating a change of course. ${ }^{28}$ Such a change may be connected with the launching in 2014 of the Guidelines for Social Responsibility in Outbound Mining Investments by the China Chamber of Commerce. ${ }^{29}$ Senior executives of CNPC and its subsidiary PetroChina have recently been arrested on corruption charges, thereby providing further indication that this was not a well-run company. ${ }^{30}$

The presence of Apple on this this list may seem incongruous. One of the world's bestknown consumer brands has apparently been unconcerned that not responding to civil society reports - particularly about sweatshop conditions at suppliers such as Foxconnmay cause reputation damage. This would then be an exception to the general rule that producers of consumer brands are more sensitive towards reputation damage and therefore more likely to respond to civil society reports. ${ }^{31}$ Perhaps the company took the view that the Apple brand is so strong that negative publicity has no impact on its sales? ${ }^{32}$

\section{International Instruments}

The UN Global Compact is the principal worldwide instrument by which companies in all industrial sectors may commit themselves to certain general principles of responsible conduct. ${ }^{33}$ Currently, more than 8,000 companies have done so. ${ }^{34}$ The Global Compact's ten principles cover human rights, labour rights, the environment, and anti-corruption but they do not contain a provision specifically requiring companies to respond to reports from civil society. ${ }^{35}$ Nevertheless, it might be expected that

28 Business \& Human Rights Resource Centre, 'Chinese National Petroleum Corporation (CNPC) Response to Reports on Alleged Human Rights Impacts of Shwe Gas \& Myanmar-China Oil Transport Projects', http://businesshumanrights.org/sites/default/files/documents/cnpc-response-re-myanmar-pipeline-5-aug-2013-en.pdf (accessed 24 July 2015).

29 China Chamber of Commerce of Metals, Minerals \& Chemicals Importers \& Exporters, 'Guidelines for Social Responsibility in Outbound Mining Investments', http://www.srz.com/files/upload/Conflict_Minerals_ Resource_Center/CCCMC_Guidelines_for_Social_Responsibility_in_Outbound_Mining_Operations_English_Version. pdf (accessed 24 July 2015).

30 David Lague, Charlie Zhu, and Benjamin Kang Lim, 'Special Report - Inside Xi Jinping's Purge of China's Oil Mandarins', Reuters (24 July 2014), http://uk.reuters.com/article/2014/07/24/uk-china-purge-cnpc-specialreportidUKKBNOFT2O020140724 (accessed 24 July 2015).

31 McBarnet, note 17.

32 For an analysis along these lines, see Mallen Baker, 'The Tricky Task of Measuring Reputation' Ethical Corporation (27 February 2012), http://www.ethicalcorp.com/communications-reporting/tricky-task-measuring-reputation (accessed 24 July 2015).

33 UN Global Compact, https://www.unglobalcompact.org/ (accessed 24 July 2015).

34 UN Global Compact, 'Our Participants', https://www.unglobalcompact.org/what-is-gc/participants (accessed 24 July 2015).

35 On the vagueness of the Global Compact's language, see Surya Deva, 'Global Compact: A Critique of the UN's "Public-Private" Partnership for Promoting Corporate Citizenship' (2006-2007) 34 Syracuse Journal of International Law \& Commerce 107, 129. For a recent critical analysis of the Global Compact, see S Prakash Seti and Donald H 
companies subscribing to the Global Compact are more responsive to civil society concerns than companies that have not committed themselves in this way. This assumption turns out to be correct. Of the 1,877 response requests in our sample 386 were addressed to companies participating in the Global Compact. The response rate to these reports was 88 per cent, i.e. significantly higher than the average response rate of 70 per cent. It is remarkable, however, that three of the companies included in Table 4 (Companies with the lowest response rate) are participants in the Global Compact: Golden Star Resources, Huawei Technologies, and Oil \& Natural Gas Corporation. They are maintained on the list of participants in the Global Compact in spite of their unresponsiveness to civil society. This can be explained by the fact that the Global Compact lacks an effective enforcement or monitoring system. A so-called Dialogue Facilitation Process has been in place for 11 years. ${ }^{36}$ Under this procedure, companies that fail to respond to credible allegations of systematic or egregious abuse of the Global Compact's principles may ultimately be delisted. ${ }^{37}$ However, only 28 cases have been raised under the Dialogue Facilitation Process so far and only two companies (Lifosa and Sui Southern Gas Company) have been delisted for failure to comply with the process. ${ }^{38}$

Casting our net wider than the Global Compact, which of the 1,317 responses in our sample referred to international instruments on business and human rights in their responses? The figures are reproduced in Table 5.

Table 5: International instruments mentioned in company responses

International instruments

UN Global Compact

Universal Declaration of Human Rights

Voluntary Principles on Security and Human Rights

UN Guiding Principles on Business and Human Rights

General commitment to respect human rights

ILO Conventions

OECD Guidelines for Multinational Enterprises
Mentioned in responses
$2.8 \%$
$1.4 \%$
$1.3 \%$
$0.8 \%$
$0.8 \%$
$0.7 \%$
$0.3 \%$

These figures show that companies are not generally in the habit of referring to international instruments or multi-stakeholder initiatives in their responses. Even the instrument referred to most frequently - the UN Global Compact-was mentioned in less than 3 per cent of responses. Only one of the numerous multi-stakeholders initiatives - the Voluntary Principles on Security and Human Rights—is mentioned with any frequency.

(F'note continued)

Schepers, 'The United Nations Global Compact: The Promise-Performance Gap' (2014) 122 Journal of Business Ethics 193.

36 UN Global Compact, 'Frequently Asked Questions about UN Global Compact', https://www.unglobalcompact.org/ AboutTheGC/IntegrityMeasures/index.html (accessed 24 July 2015).

37 UN Global Compact, 'Integrity Measures: Frequently Asked Questions', https://www.unglobalcompact.org/ AboutTheGC/IntegrityMeasures/Integrity_Measures_FAQs.html (accessed 24 July 2015).

38 Information provided to the author by the Global Compact Secretariat. Delistment for failure to submit a so-called Communication on Progress is more common. At the time of writing, 5,443 participants had been expelled for this reason. UN Global Compact, 'Expelled Participants', https://www.unglobalcompact.org/participation/report/cop/create-andsubmit/expelled (accessed 24 July 2015). 
It should be kept in mind, however, that responses occasionally refer to companies' own codes of conduct or policy statements that do contain references to international legal instruments. The comparatively few references to the Guiding Principles undoubtedly result from the fact that they were endorsed by the UN Human Rights Council only in 2011. The Global Compact had already been launched in 2000. General references to a company's commitment to respect human rights may be interpreted as an indirect reference to the Guiding Principles. What seems remarkable is that there are so few references to the OECD Guidelines for Multinational Enterprises (OECD Guidelines). This remains intriguing even if it is taken into account that the OECD Guidelines apply merely to companies based in the 34 OECD member-countries plus 12 non-OECD countries that have decided to subscribe to the OECD Guidelines. ${ }^{39}$

When interpreting these data it should also be kept in mind that it was not examined how many of the human rights reports transmitted to companies rely on relevant international instruments. It may well be that company responses often do not refer to these texts because the authors of the human rights reports did not make such references in the first place.

The European Commission has recently conducted empirical research into the extent to which EU companies refer to international instruments on corporate social responsibility in their policy statements. ${ }^{40}$ Obviously, what companies say in policy statements posted on their websites does not serve the same purpose as the responses they give to human rights reports. Moreover, the Commission's study differs from our research because it is limited to a sample of 200 large EU companies. Nevertheless, it is interesting to note that 40 per cent of the companies in the Commission's study refer to at least one international instrument on corporate social responsibility. In the Commission's study, the UN Global Compact also is the instrument most frequently referred to (32 per cent).

Taken together, these findings seem to indicate that companies generally are more inclined to mention international instruments in their policy statements than in their responses to civil society. This may seem intriguing but probably not too much should be read into it. One reason for the failure to refer to international standards may be that managers have not really internalized the codes of conduct posted on their corporate websites so that they are not able to cite the relevant provisions when appropriate. Another explanation may be that NGOs and journalists did not refer to international instruments in their reports and therefore companies did not feel the need to refer to them in their responses.

\section{Summary And Discussion of Findings}

The extractive sector remains the industrial sector that gives rise to the highest number of human rights reports. The number of reports on abuses in the information technology

\footnotetext{
39 The 12 non-OECD countries currently subscribing to the Guidelines are: Argentina, Brazil, Colombia, Costa Rica, Egypt, Jordan, Latvia, Lithuania, Morocco, Peru, Romania, and Tunisia. 'OECD Declaration and Decisions on International Investment and Multinational Enterprises', http://www.oecd.org/investment/mne/oecddeclarationanddecisions. htm (accessed 24 July 2015).

40 Caroline Schimanski, 'An Analysis of Policy References Made by Large EU Companies to Internationally Recognised CSR Guidelines and Principles', study prepared for the European Commission (March 2011), http://ec. europa.eu/enterprise/policies/sustainable-business/files/csr/csr-guide-princ-2013_en.pdf (accessed 24 July 2015).
} 
sector (covering both threats to internet freedom and working conditions in the electronics industry) is on the increase, however. While the average company response rate to human rights reports remains stable at 70 per cent there are significant differences between companies, industrial sectors, and corporate home states. The least responsive companies are state-owned conglomerates and companies based in China, India, Israel, and Russia. Companies based in Brazil and South Africa have a much higher response rate than companies headquartered in BRICS in the Northern hemisphere. Companies are generally more inclined to respond to reports about alleged abuses within their own countries than to abuses committed abroad. Companies participating in the UN Global Compact have an above average response rate but being a participant in the Global Compact does not in itself guarantee a high response rate. Company responses containing references to international instruments or multi-stakeholder initiatives are rare indeed. Less than 1 per cent of responses acknowledge that companies have a responsibility to respect human rights.

The quintessential non-responding company therefore is a state-owned corporation based in China, India, Israel, or Russia that is conducting extractive activities outside its home country. Such a company is most likely to be oblivious to due diligence requirements. Lawmakers, campaigners, and scholars are therefore advised to focus priority attention on this category of companies.

Unwillingness to respond to human rights reports does not in itself prove that a company has committed human rights abuses. But it does serve as a signal that a company does not take seriously its due diligence obligation to engage with civil society as required by the Guiding Principles. A company that repeatedly fails to respond to human rights reports criticizing fundamental aspects of its operations at the very least raises the suspicion that it is not complying with its wider human rights due diligence obligations. Unresponsiveness therefore serves as a flag that closer scrutiny, including qualitative analysis, of a company's conduct is warranted.

Two limitations should be mentioned. First, some data are more statistically reliable than others. In some cases the number of data is rather limited. For example, in Table 4 (Companies with the lowest response rate) most of the companies listed received only three or four requests to respond to a civil society report. The statistical significance of non-responses should not be overestimated in such cases.

Second, it is tempting to draw inferences from the data but this should be done with great care. For example, the fact that large numbers of reports were produced alleging abuses in certain industrial sectors or in respect of certain companies does not necessarily mean that more abuses have occurred in those sectors and companies. The explanation may simply be that NGOs or investigative journalists were more interested in those sectors and companies. Similarly, the explanation of the fact that so few international instruments were mentioned in company responses does not have to be that companies do not take those instruments seriously. The reason may also be that the instruments were not referred to in human rights reports in the first place.

\section{Conclusion}

This article has reported on the first systematic inquiry into company responses to critical civil society reports on corporate human rights abuses. Hopefully, the results and 
insights outlined here will provide new impulses both for business and human rights professionals in the field (representatives of the corporate sector, policy-makers, and human rights advocates) and for business and human rights scholarship.

Although the civil society reports covered by the present study vary widely in origin and content they have one thing in common: they were transmitted by the Resource Centre in the same manner and according to the same procedure. This similarity makes it possible to draw reliable comparisons between response rates by companies, industrial sectors, and corporate home states, and to identify global trends in respect of each of these categories. The information gathered in this way should help campaigners and regulators prioritize their work. It also should provide a benchmark for company representatives faced with critical reports.

The study reveals several avenues for further research. Two may be mentioned here. First, in addition to the quantitative research conducted in the present study, there is a need for more qualitative research. As mentioned above, the mere fact that a company issues a statement in response to specific allegations does not per se mean that it takes the matter seriously. Companies may learn that pro forma responses by their public relations departments can improve their response rates. It is also necessary, therefore, to systematically analyse and categorize the contents of responses.

Qualitative analysis raises serious methodological difficulties, however. The large amounts of data involved (thousands of company responses) are not problematic by themselves. These could be analysed through Computer Assisted Qualitative Data Analysis Software (CAQDAS). But which categories should be used and which key words and expressions should be used to allocate responses to these categories? As pointed out above, Stanley Cohen used three rubrics to categorize government responses (denial, attack on the critic, and (partial) acknowledgment of the criticism) but in his article he did not try to employ these categories in practice. ${ }^{41}$ In recent reports, the Resource Centre has started experimenting with different types of headings. For example, in a paper on human rights compliance by British companies it employed the following five headings to categorize company responses: ${ }^{42}$

0 - Failed to address the concerns raised

1 - Addressed the concerns generally and in limited detail

2 - Addressed the concerns point-by-point

3 - Addressed the concerns point-by point and showed an openness to investigate claims

4 - Addressed concerns and entered into genuine dialogue with civil society/victims

Like any categories, these are of course debatable but they would appear to be a good starting point for further research.

Second, there is a need for research on the actual impact of engaging companies through critical human rights reports. That is, further research could look at whether

41 Cohen, note 5.

42 Business \& Human Rights Resource Centre, 'Is the UK Living up to its Business \& Human Rights Commitments?'

(1 April 2015), http://business-humanrights.org/en/is-the-uk-living-up-to-its-business-human-rights-commitments (accessed 24 July 2015). 
corporate responses remained largely verbal or whether they were followed up by tangible changes or transformations within the organization or its business processes. In other words, did the allegations and the responses by the company catalyse a learning process that eventually translated into changing business policies and practices? Furthermore, are there differences between such impacts between companies that did or did not respond to the allegations? And does the thoroughness of a response foreshadow the profundity of the changes that occur within the company later on? Obviously, answering such questions is an even greater challenge than conducting qualitative analysis of responses because it raises fundamental questions about cause and effect and how to measure progress.

Scholars in business and human rights are encouraged to take up these questions and build on this initial research. For the very term responsibility entails how companies respond to moral concerns. Knowing more about company responses to critical reports, therefore, reveals something about how they interpret that responsibility. 